\title{
REASSESSMENT OF DATA USED IN SETTING EXPOSURE LIMITS FOR HOT PARTICLES
}

\author{
by
}

\author{
John W. Baum and Darryl G. Kaurin
}

\author{
RADIOLOGICAL SCIENCES DIVISION \\ DEPARTMENT OF NUCLEAR ENERGY \\ BROOKHAVEN NATIONAL LABORATORY \\ BUILDNNG 703M \\ UPTON, NEW YORK 11973, U.S.A.
}

May 1991

\section{DISCLAIMER}

\begin{abstract}
This report was prepared as an account of work sponsored by an agency of the United States Government. Neither the United States Government nor any agency thereof, nor any of their employees, makes any warranty, express or implied, or assumes any legal liability or responsibility for the accuracy, completeness, or usefulness of any information, apparatus, product, or process disclosed, or represents that its use would not infringe privately owned rights. Reference herein to any specific commercial product, process, or service by trade name, trademark, manufacturer, or otherwise does not necessarily constitute or imply its endorsement, recommendation, or favoring by the United States Government or any agency thereof. The views and opinions of authors expressed herein do not necessarily state or reflect those of the United States Government or any agency thereof.
\end{abstract}

Presented at the Workshop on Skin Dosimetry - Radiological Protection Aspects of Skin Irradiation, Dublin, Ireland, May 13-15, 1991. 
REASSESSMENT OF DATA USED IN SETTING EXPOSURE LIMITS FOR HOT PARTICLES

John W. Baum and Darryl G. Kaurin

Brookhaven National Laboratory

Building $703 \mathrm{M}$

Upton, New York 11973, U.S.A.

\section{ABSTRACT}

A critical review and a reassessment of data reviewed in NCRP Report 106 on effects of "hot particles" on the skin of pigs, monkeys, and humans were made. Our analysis of the data of Forbes and Mikhail on effects from activated $\mathrm{UC}_{2}$ particles, ranging in diameter from $144 \mu \mathrm{m}$ to $328 \mu \mathrm{m}$, led to the formulation of a new model for prediction of both the threshold for acute ulceration and for ulcer diameter. A dose of 27 Gy at a depth of $1.33 \mathrm{~mm}$ in tissue in this model will result in an acute ulcer with a diameter determined by the radius over which this dose (at $1.33-\mathrm{mm}$ depth) extends. Application of the model to the Forbes-Mikhail data yielded a "threshold" (5\% probability) of $6 \times 10^{9}$ beta particles from a point source on skin of mixed fission product beta

-This work was sponsored by the U.S. Nuclear Regulatory Commission under Contract No. DE-AC02-76CH00016. 
particles, or about $10^{10}$ beta particles from $\mathrm{Sr}-\mathrm{Y}-90$, since few of the $\mathrm{Sr}-90$ beta particles reach this depth. The data of Hopewell et al. for their $1 \mathrm{~mm} \mathrm{Sr-Y-90} \mathrm{exposures} \mathrm{were}$ also analyzed with the above model and yielded a predicted threshold of $2 \times 10^{10} \mathrm{Sr}-\mathrm{Y}-90$ beta particles for a point source on skin. Dosimetry values were employed in this latter analysis that are 3.3 times higher than previously reported for this source.

An alternate interpretation of the Forbes and Mikhail data, derived from linear plots of the data, is that the threshold deperds strongly on particle size with the smaller particles yielding a much lower threshold and smaller minimum size ulcer. Additional animal exposures are planned to distinguish between the above explanations. 


\section{INTRODUCTION}

At the present time, there is considerable interest in the dosimetry, biological effects, and appropriate regulatory limits on exposure from small, discrete radioactive particles which are frequently encountered in the working environments of nuclear power plants. These particles are often referred to as "hot particles" due to their high specific activity. They range typically in size from a few $\mu \mathrm{m}$ in diameter to a few hundred $\mu \mathrm{m}$ in diameter. Occasional pieces have major dimensions of 1 to a few millimeters. The activities contained in the particles range typically from a few $10 \mathrm{~s}$ of $\mathrm{Bq}$ to about $10^{9} \mathrm{~Bq}$ total activity. They will consist of either corrosion products, usually dominated by the presence of Co-60, or mixed fission products that result from particles which have escaped from defective fuel elements.

These particles cause non-uniform exposures when deposited on the skin because of their very small size. They produce local doses well above the required amount for cell killing. However, these doses may be considered well within acceptable radiation protection standards and limits when averaged over 1 or $100 \mathrm{~cm}^{2}$. Until recently, skin exposure in the U.S. was limited to $7.5 \mathrm{rem}(.075 \mathrm{~Gy})$ per quarter year when averaged over $1 \mathrm{~cm}^{2}$ at a depth of $70 \mu \mathrm{m}$ (or 18.75 rem for extremities). The National Council on Radiation Protection and Measurements (NCRP) in the United States, at the request of the U.S. Nuclear Regulatory Commission (NRC), reviewed the radiobiological effects literature on hot particles and summarized their conclusions and recommendations in 
NCRP Report 106, issued December 31, 1989 (1). It was recommended in this report. that "exposure to the skin from a 'point' particle or a particle of unknown size but less than $1 \mathrm{~mm}$ in diameter be limited to $10^{10}$ beta particles emitted from the radionuclides contained in the particle. Alternately the limit can be expressed as $10^{10}$ beta particles emitted from the surface of the particle." This limit was also expressed as $10 \mathrm{GBq}-\mathrm{s}$ or $75 \mu \mathrm{Ci}$-hr. The basis for this recommendation was data obtained primarily from beta particle emissions from irradiated fuel particles. The estimated dose at $70-\mu \mathrm{m}$ depth in tissue from a fission product source with this emission is about 5 Gy averaged over $1 \mathrm{~cm}^{2}$.

Subsequently, the NRC issued an enforcement policy statement (2) in which the $10^{10}$ beta particles emission criterion was accepted as a limit below which a notice of violation will not be issued for exposures due to exposure to particles $\leq 1$-mm diameter in contact with the skin. The probability of serious tissue damage from particles containing Co-60 was considered no greater than that for particles containing irradiated fuel and is likely to be much less due to the short range of the Co- 60 beta particles.

The NCRP also recommended that research should be continued on both biological effects of hot particle exposures and the dosimetry of hot particles due to limitations and uncertainties in the data on which recommendations were made. The purpose of this report is to summarize preliminary results of studies done at Brookhaven National 
Laboratory (BNL) which were aimed at resolving some of the uncertainties in the existing data and to establish a sound scientific basis for changes in the regulatory limits.

\section{BASIS FOR PRESENT RECOMMENDATIONS}

In Report 106 (1), the NCRP committee considered both stochastic and nonstochastic effects. The committee used data on humans exposed to low-energy $x$-rays (3) over skin areas that are large compared to those at risk from the hot particle exposures for assessment of stochastic effects. Much of the experimental data for non-stochastic effects, was obtained over the last decade by British scientists. They exposed young pig skin to three different isotope sources with different maximum energies ranging in size from $0.1-\mathrm{mm}$ to $40-\mathrm{mm}$ diameter. This multiple parameter research yielded information on mechanisms of damage to skin (4) as well as specific data relevant to small "hot particles." (4,5). Experiments were done in the U.S. prior to these studies, using small, fissioned fuel particles for skin exposures. Miniature swine and mice (6), monkeys $(7,8)$ and even a human subject $(7)$ were exposed.

Data on probability of ulcer formation or the size of an ulcer from a number of studies is summarized in Figure 1. The data from the studies of Forbes and Mikhail (6) which employed fission fuel particles having $150 \mu \mathrm{m}$ and $300 \mu \mathrm{m}$ nominal diameters are plotted on the right in Figure 1 which indicates ulcer size (right ordinate) versus number of beta particles emitted from the source. Three human data points plotted on the 
abscissa yielded no ulcers from fission fuel particles of about $200-\mu \mathrm{m}$ diameter placed directly on human skin. The human data point at $6.5 \times 10^{9}$ beta particles yielded a small. dry desquamation. A single-mouse data point at $1.6 \times 10^{10}$ beta emissions was obtained in the work of Forbes and Mikhail (9) and is of some interest since a small ulcer and tumor were produced by this exposure. The solid line, representing the Hopewell et al. (4) Sr-Y-90 (and possibly Tm-179) particles of $\leq 1-\mathrm{mm}$ diameter, reflects the ulcer incidence (left ordinate) that would be predicted based on doses they measured in a 1.1mm diameter extrapolation chamber. These doses were converted to the number of beta particles that would be required from a point source on skin to produce the same dose at 16- $\mu \mathrm{m}$ depth in tissue.

The resulting threshold at about $2 \times 10^{9}$ beta particles can be compared to a value of $1 \times 10^{10}$ beta particles deduced by the NCRP from the Forbes-Mikhail data. The NCRP reduced the extrapolated value of $3 \times 10^{10}$ beta particles by a factor of 3 to account for the fewer betas needed from a point source on skin to produce the same dose at $100-\mu \mathrm{m}$ depth in tissue, as that produced by the particles used in the ForbesMikhail experiment. One of the principal reasons for the reanalysis of this data was the desire to understand possible reasons for this difference of about a factor of five in apparent threshold between the Hopewell and Forbes-Mikhail results. 


\section{REANALYSIS OF DATA OF FORBES AND MIKHAIL}

In NCRP Report 106 and the Forbes and Mikhail report (6), data were plotted as shown on Figure 1. i.e., ulcer diameter on a linear scale along the ordinate, versus the number of beta particles on a logarithmic scale on the abscissa. It is of considerable interest to note that if the same data are plotted on linear scales as shown in Figure 2, the data from the $150-\mu \mathrm{m}$ diameter particles extrapolate to an entirely different threshold number of beta particles than would be predicted for the $300-\mu \mathrm{m}$ diameter particles. Linear regression analysis using only the $150-\mu \mathrm{m}$ diameter particle yields a threshold of $(5 \pm 17) 10^{9}$ beta particles, whereas $300-\mu \mathrm{m}$ diameter particles yield an intercept at $(-2 \pm 0.3) \times 10^{12}$ beta particles (9). These results clearly demonstrate the difficuliy encountered in deriving a threshold from these data since the uncertainties extend to zero dose.

Regression analysis on the $300-\mu \mathrm{m}$ diameter particles also yielded a minimum ulcer diameter of $(3.8 \pm 0.3) \mathrm{mm}$. Ulcers of this diameter require that $3.5 \times 10^{11}$ beta particles from $300-\mu \mathrm{m}$ diameter particles, indicating a much higher (one or two orders of magnitude) threshold than that for $150-\mu \mathrm{m}$ diameter particles.

A number of regression analysis were run in an attempt to find a correlation relation that would yield common results for both particle sizes because results from the small and large particle sizes seem to fit entirely different regression lines. Both ulcer 
diameter and ulcer area were employed as dependent variables in these regressions and dose was expressed either as number of beta particles emitted, or as point dose at various depths in tissue. The details of these analyses will be found in the progress report on this subject (9). It was concluded from these studies that the small and large particles both fit a common line if dose at $1.33-\mathrm{mm}$ depth in tissue at the ulcer radius is used as the critical parameter. Resulıs for this regression analysis are summarized on Figure 3, which shows dose at depth $1.33 \mathrm{~mm}$ in tissue at the ulcer radius versus area of the ulcer. The horizontal line, which intercepts the ordinate at $27 \mathrm{~Gy}$, represents the best fit to these data and has approximately zero slope, indicating that the same critical dose is observed at the radial point for all ulcers.

The computer code used most frequently for hot particle dose calculations in the U.S. is the VARSKIN code (10). This code was used to estimate the number of beta particles that would be required to produce $27 \mathrm{~Gy}$ at $1.33-\mathrm{mm}$ depth in tissue, assuming a source of particles having $2.25 \mathrm{MeV}$ maximum energy (Yttrium-90 beta particles), which is the approximate average maximum beta particle energy emitted by the fission product sources (11) employed by Forbes and Mikhail. The resulting number of beta particles was increased by a factor of 1.3 to account for the greater number of beta particles required from a point source in air (12), as contrasted to a point source located in an infinite tissue-like medium as assumed in the VARSKIN code. This yielded a result of $2.4 \times 10^{10}$ beta particles emitted from the source. A large variability of dose was incurred by the four particles that yielded the smallest ulcer area (approximately $0.5 \mathrm{~mm}$ in 
diameter) as can be seen in Figure 3. The standard deviation of the dose for these four points when converted to beta particle emission is $\pm 1.1 \times 10^{10}$ beta particles emitted. The data in Figure 3, when extrapolated to zero ulcer area, imply that when the dose directly below the particle is $27 \mathrm{~Gy}$ at $1.33-\mathrm{mm}$ depth, the expected ulcer diameter is zero and a threshold has been reached. The above mean result of $2.4 \pm 1.1 \times 10^{10}$ beta particles at threshold can be used to infer various probabilities based on the tails in a normal distribution function assuming data points about this thresholu are distributed normally. Thus, one predicts $5 \%$ chance that an ulcer may be detected at 1.65 standard deviations from the mean or at $6 \times 10^{9}$ beta particles. This number of beta particles from a point source on skin for particle emitters such as Sr-Y-90 would produce a dose at $70-\mu \mathrm{m}$ depth in tissue of about 3 Gy averaged over $1 \mathrm{~cm}^{2}$.

\section{REANALYSIS OF HOPEWELL ET AL. DATA}

Extensive studies of effects of discrete radioactive particles on pig skin conducted by Hopewell et al. (4) were made using an extrapolation-type ionization chamber for dosimetry. Most of the measurements reported were made with a $1.2-\mathrm{mm}$ diameter collecting electrode and $16 \mu \mathrm{m}$ thick plastic chamber window. Several preliminary measurements made with this instrument using a variety of source sizes and collecting electrode diameters were reported by Wells (13). One measures charge collected (or current if dose rate is to be measured) in the ionization chamber at various spacings of the collecting electrodes in using this type of instrument. Then one plots values of 
current collected versus electrode spacing. These measurement results plot as a straight line if the chamter is uniformly irradiated, and the slope of this line provides a measure of dose rate averaged over the collecting volume. However, ionization produced throughout the chamber is extremely non-uniform when a small radioactive particle is placed near the center of the ionization chamber window. Plots of current versus electrode spacing may be non-linear, under these conditions, especially for chambers with small electrode diameters.

A reanalysis of extrapolation chamber data for the $0.1 \mathrm{~mm}$ and $0.5 \mathrm{~mm} \mathrm{Tm}-170$ sources employed in the Hopewell et al. studies was made based on data provided to us by M. Charles. Polynomial fits using linear, quadratic, and cubic functions revealed that quadratic functions yielded extrapolated dose rates. 7 to $60 \%$ higher than linear fits and cubic functions yielded extrapolations 2 to 2.5 times higher. These very preliminary evaluations were followed by more detailed studies being reported by Soares et al. (14) and Darley et al. (15).

The 1-mm diameter Sr-Y-90 source employed in some of the Hopewell et al. work was examined again using radiochromic dye film as a dosemeter (14) since the results from the small extrapolation chamber used in the British studies were in need of reevaluation, and the $\mathrm{Tm}-170$ sources have decayed and been discarded. Five layers of radiochromic dye film were placed in a stack, in these studies which permitted measurement of dose at various depths in tissue including one at $16-\mu \mathrm{m}$ to $22-\mu \mathrm{m}$ depth for 
comparison with the results from the British extrapolation chamber. Results from the radiochromic dye film studies yielded dose rates 3.3 times higher than predicted from those that had been measured using the extrapolation chamber. Thus, much of the difference between apparent thresholds shown in Figure 1 may be due to (a) erroneousiy low doses originally reported for the British study, and (b) to a difference in definition of threshold. Threshold deduced for the Forbes-Mikhail studies may be lower by a factor of about 2 than that reported by the NCRP if $95 \%$ probability of a small ulcer as derived above is used as a definition of a threshold.

The most recent report of the Hopewell et al. $(16,17)$ studies using particles of $\leq 2$-mm diameter are summarized in Table 1. The second column in Table 1 lists doses reported by Hopewell et al. to produce acute ulceration with $50 \%$ probability $\left(\mathrm{ED}_{\varsigma_{0}}\right)$; column 3 provides data for $10 \%$ probability $\left(\mathrm{ED}_{10}\right)$; and column 4 gives an estimate of threshold proposed by Charles (16), i.e., $2 / 3$ of $E D_{10}$. An alternate estimate of threshold derived in this work is based on fitting the $E D_{50}$ and $E D_{10}$ values to a normal distribution function and calculating the $\mathrm{ED}_{5}(5 \%$ probability) value. The results for this method are given in column 5 of Table 1. The agreement between the $2 / 3 E D_{10}$ value and the $\mathrm{ED}_{5}$ value is fairly good for most particles listed. However, the $\mathrm{ED}_{5}$ value

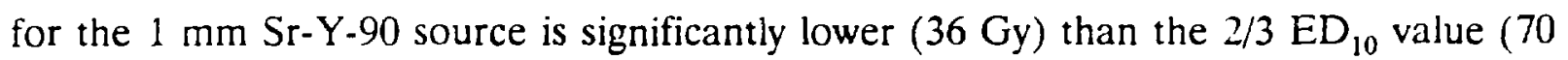
Gy). The former value was used in this work and multiplied by 3.3 to yield a corrected threshold dose of $120 \mathrm{~Gy}$ at $16-\mu \mathrm{m}$ depth averaged over $1.1 \mathrm{~mm}^{2}$ of tissue. Corresponding doses at $125-\mu \mathrm{m}$ and $1.33-\mathrm{mm}$ depths, and averaged over $1 \mathrm{~cm}^{2}$ at each of these 
depths, were obtained from the radiochromic dye film studies (14). These results are summarized in Table 2 (note that dose measured at $19-\mu \mathrm{m}$ depth in dye film is used to approximate the $16-\mu \mathrm{m}$ depth applicable to Hopeweil data).

The number of beta particles per Gy at each depth (averaged over $1.1 \mathrm{~mm}^{2}$ or $1 \mathrm{~cm}^{2}$ ), for a point Sr-Y-90 source on skin, was estimated using outputs from the :ARSKIN code corrected by a factor of 1.3 for less backscatter in an air/tissue interface. These results shown in Table 3 were then used to obtain the threshold number of beta particles corresponding to the three depths and two areas (six values in ali). The results. also shown in Table 3, vary from $2.2 \times 10^{9}$ beta particles based on dose measured at 19 $\mu \mathrm{m}$ depth and averaged over $1.1 \mathrm{~mm}$ to 1.8 to $1.9 \times 10^{10}$ beta particles based on dose at $1.33-\mathrm{mm}$ depth averaged over $1 \mathrm{~cm}^{2}$ or $1.1 \mathrm{~mm}^{2}$. This large difference results from differences in depth-dose variations expected for point sources on skin compared to depth-dose variations measured using the $1-\mathrm{mm}$ diameter $\mathrm{Sr}-\mathrm{Y}-90$ source. This source was contained in a cylindrical holder having $0.5 \mathrm{~mm}$ thick stainless steel walls and a 50 $\mu \mathrm{m}$ thick stainless steel window. Thus, the effective center of the source was much farther from the skin (or its basal epidermal layer) than for a point source.

\section{CONCLUSIONS}

Reevaluation of data on acute effects of hot particles on pig skin revealed large uncertainties in the value for number of beta particles needed for production of acute 
ulceration, and possibly a large difference in the value of the threshold number of beta particles for $\mathrm{LC}_{2}$ particles with nominal diameters of 150 vs. $300 \mu \mathrm{m}$. The larger particles may yield only larger ulcers (e.g., 3-mm diameter) at higher exposures (e.g., $10^{11}$ beta particles).

An alternate interpretation of the data, based on a model deduced from the Forbes and Mikhail results, leads to the conclusion that from $6 \times 10^{9}$ to $2 \times 10^{10}$ beta particles may be required to induce small acute ulcers with $5 \%$ probability for high energy beta particle emitters such as mixed fission product sources or Sr-Y-90 sources. Tissues at depth of about $1.33 \mathrm{~mm}$ seem important for $\mathrm{t}$ is end point. This implies a significant beta particle energy dependence for these effects, with rapid decrease in probability of effect for beta particle sources having maximum energy below about 0.8 $\mathrm{MeV}$. 
Table 1. Probability of Acute Ulceration based on data of Hopewell et al., 1986, and Charles, 1990.

\begin{tabular}{|c|c|c|c|c||}
\hline Source & \multicolumn{4}{|c|}{$1.1-\mathrm{mm}^{2}$ Dose $(\mathrm{Gy})^{*}$ at $16-\mu \mathrm{m}$ Depth } \\
\hline$(1)$ & $\begin{array}{c}(2) \\
E_{50}\end{array}$ & $\begin{array}{c}(3) \\
E_{10}\end{array}$ & $\begin{array}{c}(4) \\
\mathrm{ED}_{10}\end{array}$ & $\begin{array}{c}(5) \\
E_{5} \\
\text { (Uncorrected) }\end{array}$ \\
\hline$\underline{\mathrm{Tm}-170}$ & & & & \\
\hline $0.1 \mathrm{~mm}$ & 197 & 85.7 & 57 & 56 \\
\hline $0.5 \mathrm{~mm}$ & 339 & 147 & 98 & 95 \\
\hline $1 \mathrm{~mm}$ & 202 & 87.7 & 59 & 57 \\
\hline $2 \mathrm{~mm}$ & 179 & 77.7 & 52 & 68 \\
\hline$\underline{\text { Sr-Y-90 }}$ & & & & 36 \\
\hline $1 \mathrm{~mm}$ & 353 & 104 & 70 & 72 \\
\hline $2 \mathrm{~mm}$ & 119 & 82 & 55 & \\
\hline
\end{tabular}

*The $1-\mathrm{mm}$ diameter $\mathrm{Sr}-\mathrm{Y}-90$ values need to be adjusted upward by a factor of 3.3 based on dye-film studies. Corrections for Tm-170 are likely to be of the same order. 
Table 2. Results from Radiochromic Dye Film Dosimetry

Study of British $1 \mathrm{~mm} \mathrm{Sr-Y-90} \mathrm{"Point"} \mathrm{Source}$

\begin{tabular}{|c|c|c|c|c|c|c|}
\hline Film Position & $\begin{array}{l}\text { Depth } \\
(\mu \mathrm{m})\end{array}$ & $\begin{array}{c}\text { Dye Film } \\
1.1 \mathrm{~mm}^{2} \\
\text { Area } \\
\text { Average } \\
\text { Dose Rate } \\
(\mathrm{Gy} / \mathrm{s})\end{array}$ & $\begin{array}{c}\text { (Relative } \\
\text { to } \\
\text { Extrapolation } \\
\text { Chamber }^{*} \text { ) }\end{array}$ & $\begin{array}{c}\text { Dye Film } \\
1 \mathrm{im}^{2} \\
\text { Area } \\
\text { Average } \\
\text { Dose Rate } \\
\text { (Gy/s) }\end{array}$ & $\begin{array}{c}\text { (Relative } \\
\text { to } \\
\text { Extrapolation } \\
\text { Chamber*) }\end{array}$ & $\begin{array}{l}(16-\mathrm{km} \text { depth. } \\
1.1-\mathrm{mm}^{-} \text {Dose } \\
\text { rate }) \div \\
\left(1 \mathrm{~cm}^{2} \text { uose }\right. \\
\text { rate })^{* *}\end{array}$ \\
\hline $\mathrm{N}$ & 19 & 2.58 & (3.3) & 0.0629 & $(0.079)$ & +1 \\
\hline$x+1$ & 125 & 1.78 & $(2.3)$ & 0.0549 & $(0.069)$ & 47 \\
\hline$x+2$ & 231 & 1.35 & $(1.7)$ & 0.0467 & $(0.059)$ & 55 \\
\hline$\therefore+3$ & 1.337 & 0.190 & $(0.33)$ & 0.0237 & $(0.030)$ & 109 \\
\hline$x+4$ & 1.443 & 0.173 & $(0.30)$ & 0.0227 & $(0.029)$ & 114 \\
\hline
\end{tabular}

×Extrapolation chamber dose raie at $16-\mu \mathrm{m}$ depth corrected for decay $=0.79 \mathrm{~Gy} / \mathrm{s}$.

* This ratio provides a factor that may be used to obtain dose averaged over $1 \mathrm{~cm}^{2}$ at various depths from a measurement obtained with the extrapolation chamber, which measures dose rate averaged over $1.1 \mathrm{~mm}^{2}$ at $16-\mu \mathrm{m}$ depth. 
Table 3. Threshold Number of Beta Particles Deduced from

Hopewell's 1-mm Diameter Sr-Y-90 Exposures and

Corrected (Dye Film) Dosimetry Results

\begin{tabular}{|c|c|c|c|}
\hline & \multicolumn{3}{|c|}{ Depth in Tissue } \\
\hline & $19 \mu \mathrm{m}$ & $125 \mu \mathrm{m}$ & $1.33 \mathrm{~mm}$ \\
\hline $\begin{array}{l}\text { Threshold Dose Avg. } \\
\text { over } 1.1 \mathrm{~mm}^{2} \text { (Gy) }\end{array}$ & 120 & 82 & $8.7(9.6)^{* *}$ \\
\hline $\begin{array}{l}\text { Beta Yarticles* } \\
\text { per Gy for } 1.1 \mathrm{~mm}^{2} \\
\text { Area Dose }\end{array}$ & $1.8 \times 10^{7}$ & $5.1 \times 10^{7}$ & $2.0 \times 10^{9}$ \\
\hline $\begin{array}{l}\text { Threshold No. of } \\
\text { Beta Particles } \\
\text { Based on } 1.1 \mathrm{~mm}^{2} \\
\text { Area Dose }\end{array}$ & $2.2 \times 10^{9}$ & $4.2 \times 10^{9}$ & $1.9 \times 10^{10}$ \\
\hline $\begin{array}{l}\text { Threshold Dose Avg. } \\
\text { over } 1 \mathrm{~cm}^{2}(\mathrm{~Gy})\end{array}$ & 2.9 & 2.5 & $1.1(1.2)^{* *}$ \\
\hline $\begin{array}{l}\text { Beta Particles* per } \\
\text { Gy for } 1 \mathrm{~cm}^{2} \text { Area Dose }\end{array}$ & $1.3 \times 10^{9}$ & $2.8 \times 10^{9}$ & $1.5 \times 10^{10}$ \\
\hline $\begin{array}{l}\text { Threshold No. of } \\
\text { Beta Particles Based } \\
\text { on } 1 \mathrm{~cm}^{2} \text { Area Dose }\end{array}$ & $3.7 \times 10^{9}$ & $7.0 \times 10^{9}$ & $1.8 \times 10^{10}$ \\
\hline
\end{tabular}

*Number of beta particles frne a point source on the skin.

${ }^{* *}$ Doses in parentheses are those estimated from tnose measured in dye film studies. Measured values were increased by $10 \%$ for $1.1-\mathrm{mm}^{2}$ area dose and by $5 \%$ for $1-\mathrm{cm}^{2}$ area dose to compensate for the lower density and attenuation of tissue of unit density. These tissues doses were then used to estimate threshold $\left(\mathrm{ED}_{5}\right)$ number of beta particles. 


\section{REFERENCES}

1. "Limit for Exposure to 'Hot Particles' on the Skin," NCRP Report No. 106. Vational Council on Radiation Protection and Measurements, 7910 Woodmont Arenue. Bethesda, MD. December 31, 1989.

2. "Modified Enforcement Policy for Hot Particle Exposures - Revision to Incorporate Recommendations Made in NCRP No. 106," memorandum for the Commissioners from James M. Taylor, Executive Director for Operations, SECY-90-169. May 11, 1990. .

3. Shore, Albert. Reed, Harley, and Pasternak, "Skin Cancer Incidence Among Children Irradiated for Ringworm of the Scale," Radiation Research 100, 192, 1981.

4. Hopewell. J.W.. Coggle, J.E., Wells, J., Hamlet, R., Williams, J.P., and Charles, M.W., "The Acute Effects of Different Energy Beta-Emitters on Pig and Mouse Skin," Brit. J. Radiol., Suppl. 19, 47, 1986.

5. Peel et al., "Nonstochastic effects of different energy beta-emitters on pig skin," Radiation Research 99, 372 (1984).

6. Forbes. P.D. and Mikhail, S.Z., "Acute Lesions in Skin Produced by Radioactive Microspheres." Oral presentation at the Annual Meeting of the Radiation Research Society, abstract in Radiation Research, 39, 493, 1969.

7. Dean. P.N., Langham. J. and Holland, L.J., "Skin Response to a Point Source of Fissioned Lranium-235 Carbide," Health Physics, 19, 3, 1970.

8. Dean, P.N. and Langham, W.H., "Tumorigenicity of Small Highly Radioactive Particles," Health Physics, 16, 79, 1969.

9. Baum, J.W., Kaurin, D.G., Waligorski, M., Bird, R., and Sun, L.C., "Progress Report on Hot Particle Studies," NUREG/CR-5725, BNL-NUREG-52287, 1991.

10. Traub, R.J., Reece, W.D., Scherpelz, R.I., and Sigalla, L.A., "Dose Calculation for Contamination of the Skin Using the Computer Code VARSKIN," NUREG/CR4418. Pacific Northwest Laboratory, Richland, WA, August 1987.

11. Ulberg, J.C. and Kochendorfer, D.B., "Model for Estimating Beta Dose to Tissue from Particle Debris in Aerospace Nuclear Applications," USNRDL-TR-1107, Springfield, VA. 1966. 
12. Crciss, W.G., Wong, P.Y., and Freedman. N.O., "Beta-Ray Depth Dose Distributions from Incident Beams and Skin Cortamination," Presented at the Health Physics Society Annual Meeting, Anaheim, CA, June 1990.

13. Wells. J., "Extrapolation Ionization Chamber Measurements on Beta-Emitting Sources Produced for the CEGB Collaboratorive Radiobiology Programme." TPRD, B,0867.R88. Central Electricity Generating Board. Berkeley Nuclear Laboratories. Berkeley, Gloucestershire, England, June 1979.

14. Soares et al., "Hoi Particle Dosimetry Using Extrapolation Chambers and Radiochromic foils," Presented at the Workshop on Skin Dosimetry - Radiological Protection Aspects of Skin Irradiation, Dublin, Ireland, May 13-15, 1991.

15. Darley et al., "Dosimetry of Planar and Punctiform Beta Sources using an Automated Extrapolation Chamber and Radiochromic Dye Films," Presented at the Workshop on Skin Dosimetry - Radiological Protection Aspects of Skin Irradiation, Dublin, Ireland, May 13-15, 1991.

16. Hopewell, J.W., "The Skin: Its Structure and Response to Ionizing Radiation." Int. J. Radiat. Biol., Vol. 57, No. 4, pp. 751-773, 1990.

17. Charles, M.W., "General Considerations of the Choice of Dose Limits, Averaging Areas and Weighting Factors for the Skin in the Light of Revised Skin Cancer Risk Figures and Experimental Data on Non-Stochastic Effects," Int. J. Radiat. Biol., Vol. 57, No. 4, pp. 841-858, 1990. 


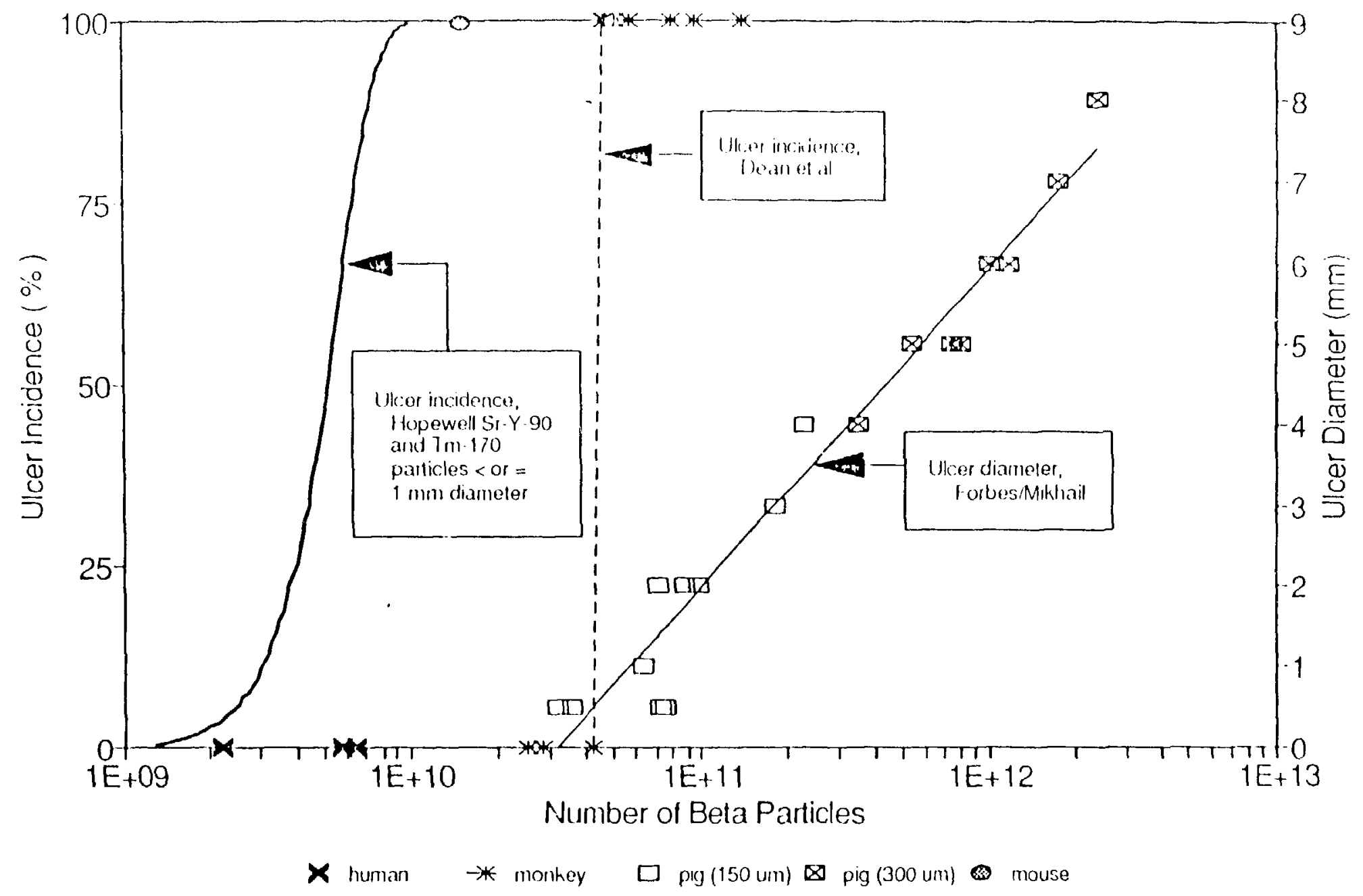

Figure 1. Ulcer incidence or ulcer diameter vs. number of beia particles emitted. Monkey data (*) of Dean et al. (1970) includes 7 points along the $100 \%$ incidence axis (only the lowest emission point is plotted). The single mouse point (\$) also caused a tumor at the exposure site. 


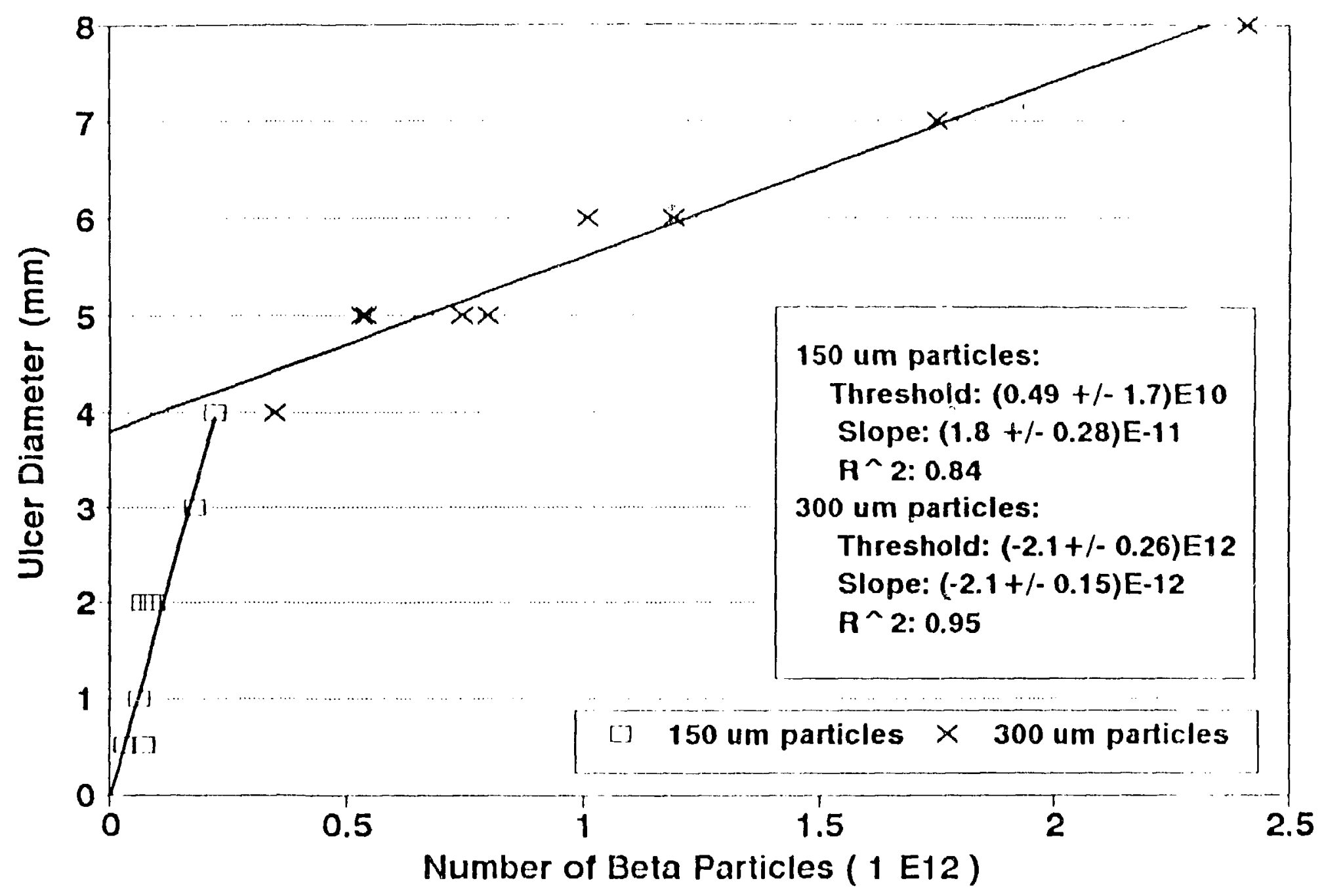

liggure 2. Number of beta particles vs. uker diameter for data of Forbes and Mikhail (I0S9). 


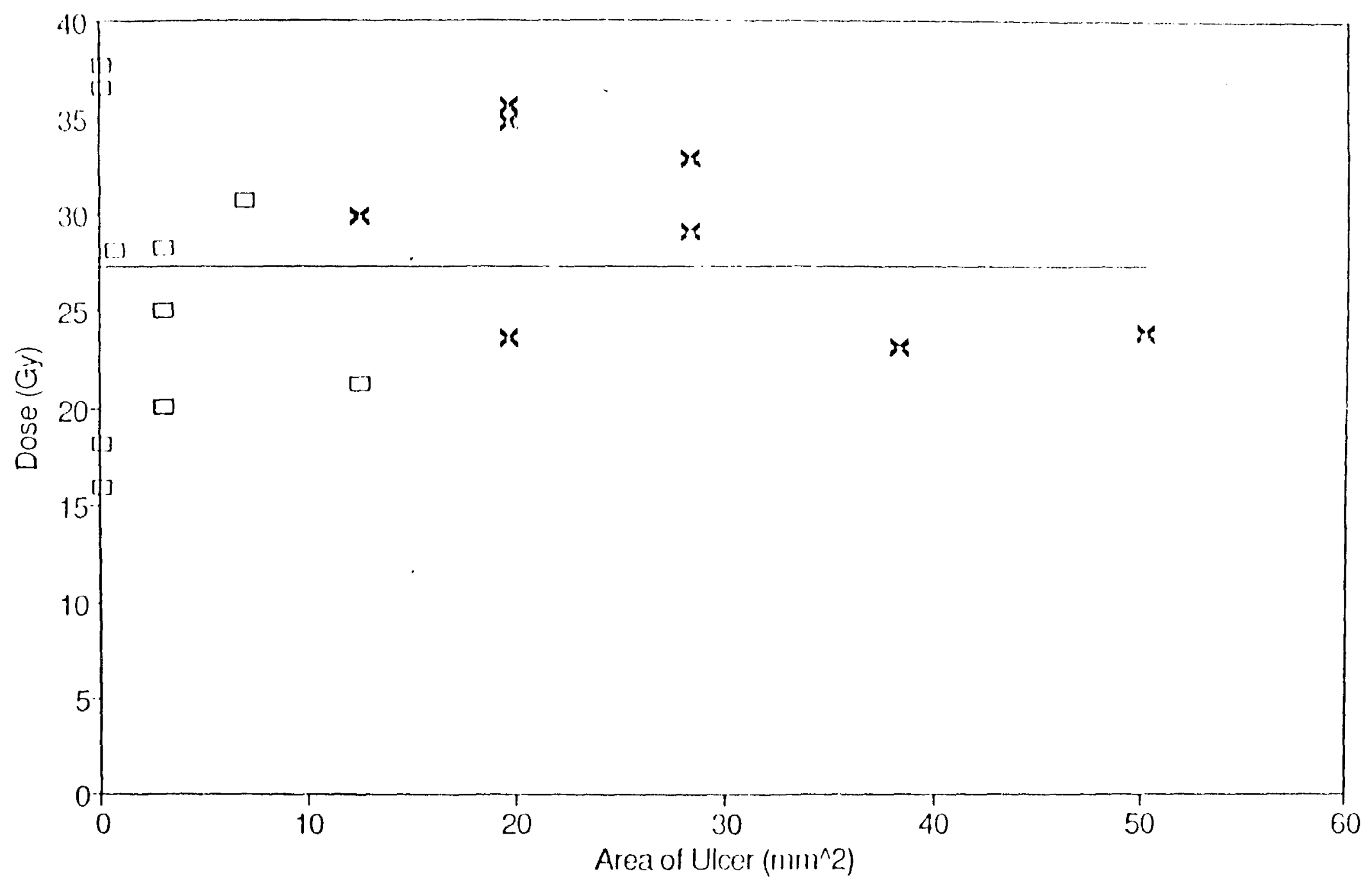

$\square 150$ umparticles $\times 300$ umparticles

Figure 3. Dose at 1.33-mm depth below radius of ulcer for Forbes and Mikhail (1989) data. 